\title{
KARAKTERISTIK SARANG TARSIUS (Tarsius spectrum) DI CAGAR ALAM TANGKOKO BITUNG SULAWESI UTARA
}

\author{
Aktor Eben Lowing*), S. C. Rimbing $\left.{ }^{* *}\right)$ G. D. G. Rembet ${ }^{* * *}$ ), dan M. J. Nangoy ${ }^{* * *}$ ) \\ Fakultas Peternakan Universitas Sam Ratulangi Manado, 95115. \\ email: aktoreben@gmail.com
}

\begin{abstract}
ABSTRAK
Tujuan penelitian ini adalah mendeskripsikan mengenai karakteristik sarang Tarsius. Diharapkan dengan deskripsi ini dapat dibuat suatu modifikasi sarang Tarsius. Manfaat yang diharapkan adalah memberikan informasi mengenai karakteristik sarang Tarsius di Cagar Alam Tangkoko dan sebagai referensi pengetahuan dalam bidang konservasi satwa langkah dan endemik. Penelitian ini dilaksanakan di Cagar Alam Tangkoko Batuputih Bitung Sulawesi Utara selama 61 hari dengan menggunakan 10 sampel sarang Tarsius. Penelitian ini menggunakan metode observasi. Variabel penelitian ini adalah Jenis vegetasi, bentuk sarang, lingkaran pohon dan ketinggian sarang dari permukaan tanah, suhu dan kelembaban sarang dan variabel penunjang antara lain adalah ketinggian sarang dari permukaan laut (mdpl) dan vegetasi sekitar sarang. Berdasarkan hasil penelitian jenis vegetasi, ditemukan bahwa semuanya adalah pohon jenis Ficus $s p$ dengan rataan lingkaran pohon adalah 8,169 m. Bentuk sarang Tarsius tidak beraturan dan lubang sarang umumnya berbentuk bulat lonjong dan berbentuk persegi dengan ketinggian sarang antara $1,5 \mathrm{~m}$ sampai $13 \mathrm{~m}$. Suhu dalam sarang Tarsius antara $20,97^{\circ} \mathrm{C}$ sampai $23,92^{\circ} \mathrm{C}$ dan kelembaban sarang Tarsius antara $77,3 \%$ sampai $81,4 \%$. Rataan ketinggian sarang dari permukaan laut adalah $53 \mathrm{mdpl}$. Vegetasi di sekitar sarang Tarsius ditemukan 24 jenis vegetasi yang di dominasioleh vegetasi jenis Leea indica dari famili Leeaceae.
\end{abstract}

\footnotetext{
*Alumni Fakultas Peternakan

** Jurusan Produksi Ternak
}

\section{Kata Kunci:Maleo, Karakteristik sarang, Tangkoko.}

\section{ABSTRACT}

CHARACTERISTICS NESTS TARSIER (Tarsiusspectrum) IN TANGKOKO NATURERE SERVE BITUNG, NORTH SULAWESI. This study aimed to describe the characteristics of the nest Tarsier. Hopefully with this description could be made of a modified nest Tarsier. The expected benefits is to provide information on the characteristics of the nest Tarsier Nature Reserve Tangkoko andas a reference knowledge in the field of wild life conservation measures and endemic. This research was conducted in the Nature Reserve Tangkoko Batu putih Bitung North Sulawesi for 61 days using 10 samples Tarsier nest using observational methods. The research variables are vegetation type, form nests, tree rings and nest height from ground level, temperature and humidity of the nest andsupporting variables include nest height above sea level (masl) and vegetation around the nest. Based on the studyof vegetation types, it was found that itis akind of tree Ficusspwith the average tree rings is $8.169 \mathrm{~m}$. Tarsier nest irregular shapes and nest holes generally oval-shaped and square-shaped nest with a height ofbetween $1.5 \mathrm{~m}$ to $13 \mathrm{~m}$. The temperature in the nest Tarsius between $20.97^{\circ} \mathrm{C}$ to $23.92^{\circ} \mathrm{C}$ and humidity of the nest Tarsier between $77.3 \%$ to $81.4 \%$. Mean nest height from sea levelis 53 meters above sea level. Vegetation around nests Tarsier found 24 types of vegetation is dominated by vegetation type Leea indica of family Leeaceae. 
Keywords: Maleo,Characteristicsnests, Tangkoko.

\section{PENDAHULUAN}

Tarsius (Tarsius spectrum) adalah satwa primata primitif (prosimii) dari famili Tarsidae yang merupakan satwa endemik Sulawesi Utara. Satwa ini memiliki tubuh yang kecil dengan mata bulat besar dan dilihat sepintas seperti beruang mini sehingga satwa ini dapat dikategorikan sebagai satwa eksotik atau satwa unik. Tarsius termasuk satwa yang aktif pada malam hari (nokturnal) dan mencari makan dengan cara melompat dari pohon yang satu ke pohon lain. Tarsius mendiami rongga-rongga pohon ataupun pada tumpukan akar.

Tarsius ditemukan di hutan hujan primer dan sekunder, meskipun mereka lebih memilih hutan pertumbuhan sekunder. Hal ini mungkin karena kelimpahan yang lebih besar dari makanan di hutan pertumbuhan sekunder. Mereka tersebar dari habitat hutan hujan dataran rendah dekat permukaan laut ke hutan hujan pegunungan rendah sampai $1500 \mathrm{~m}$. Tarsius juga telah ditemukan di hutan bakau dan hutan semak belukar (Wright, et al, 2003 dalam Shekelle dkk 2008).

Sarang Tarsius merupakan tempat yang dianggap aman dari serangan predator. Selain itu juga tempat yang didiami Tarsius memiliki sumber makanan yang dapat memenuhi kebutuhan Tarsius. Sarang merupakan tempat bernaung dan beristirahat bagi satwa. Tarsius hidup berkelompok disetiap sarang. Biasanya dalam satu sarang terdapat 3-7 ekor Tarsius.

Tarsiusmempunyaiperanpenting dalamekosistem, yaituberfungsi sebagai satwa yang mengendalikan populasi serangga dengan statusnya sebagai pemakan serangga (insektivora). Tarsius digolongkan dalam satwa yang dilindungi karena satwa ini dikategorikan dalam IUCN dengan status rentan (vulnerable) dan tercantum didalam CITES appendix II yang kemungkinan akan punah akibat perdagangan satwa liar. Sampai saat ini populasi Tarsius cenderung mengalami penurunan (IUCN, 2012). Perkiraan kepadatan populasi Tarsius di Tangkoko adalah 156/km2 (Gursky 1997). Hal ini karena dipengaruhi oleh faktor-faktor baik dari dalam (internal) maupun dari luar (eksternal). Faktor luar (eksternal) yang mempengaruhi Tarsius antara lain adalah lingkungan (habitat, sarang, jenis vegetasi), iklim (suhu, kelembaban, intensitas cahaya, dan curah hujan), predator (kucing hutan, yaki, ular dan manusia), dan pakan Tarsius (jenis serangga, tikus kecil, ular kadal dan burung).

Pelestarian Tarsius penting untuk peningkatan populasi Tarsius. pelestarian ini dapat dilakukan dengan metode penangkaran Tarsius baik di habitat asli (in-situ) dan diluar habitat aslinya (ex-situ). Untuk penangkaran Tarsius diluar habitat aslinya (ex-situ) diperlukan pemahaman karakteristik sarang Tarsius sehingga penangkaran Trasius diluar habitat aslinya (in-situ) dapat berjalan dengan baik.

Berdasarkan uraian sebelumnya maka dilakukan penelitian mengenai karakteristik sarang Tarsius (Tarsius spectrum) di Cagar Alam Tangkoko Bitung Sulawesi Utara

\section{MATERI DAN METODE PENELITIAN}


Penelitian ini dilaksanakan di Cagar Alam Tangkoko Batuputih Bitung Sulawesi Utara. Lama penelitian 61 hari dimulai dari bulan April hingga bulan Juni 2012. Penelitian ini menggunakan 10 sampel sarang Tarsius yang berada di Cagar Alam Tangkoko Bitung Sulawesi Utara.

Peralatan Penelitian :

- alat ukur suhu dan kelembaban (Thermo hygrometer).

- alat ukur ketinggian dari permukaan laut (Altimeter)

- senter

- pita ukur

- binokuler

- kamera

- alat tulis menulis.

Penelitian ini menggunakan metode observasi yakni penelitian dengan cara pengamatan langsung di tempat penelitian. Penelitian ini dilakukan dengan dua tahap, yaitu :

1. Tahap pendahuluan dilakukan untuk mencari objek pengamatan dalam hal ini adalah pohon yang dijadikan sarang oleh Tarsius kemudian di identifikasi pohon tersebut selama 14 hari. Selanjutnya penandaan dan penomoran pohon sarang Tarsius dilakukan selama 5 hari.

2. Tahap pengamatan dilakukan pada masing-masing variable mulai dari variable utama yang terdiri dari jenis vegetasi, lingkaran pohon, bentuk sarang, ketinggian sarang dari permukaan tanah serta suhu dan kelembaban sarang. Pengamatan tersebut dilakukan selama 37 hari. Pengamatan selanjutnya mengenai variable penunjang, yaitu ketinggian sarang dari permukaan laut (mdpl) dan jenis vegetasi lain di sekitar sarang dilakukan selama 5 hari. Dan pengukuran ketinggian sarang dari permukaan laut menggunakan alat altimeter.

Variabel yang diamati dalam penelitian ini adalah mengenai karakteristik sarang Tarsius antara lain:

1. VariabelUtama

1. Jenis vegetasi, lingkaran pohon, bentuk sarang dan ketinggian sarang dari permukaan tanah

Menentukan jenis vegetasi yang dijadikan sarang Tarsius dengan cara pengamatan langsung. Pengamatan ini dilakukan pada siang hari dengan mengamati pohon yang dijadikan sarang Tarsius. Pengukuran lingkaran pohon sarang menggunakan alat pita ukur kemudian dilingkar pada pohon. Pengamatan bentuk sarang dengan cara pengamatan langsung kemudian mendeskripsikannya. Pengukuran ketinggian sarang dari permukaan tanah dilakukan dengan menggunakan alat pita ukur. Pengukuran dilakukan dengan menentukan tempat pertama kali Tarsius terlihat.

2. Suhu dan kelembaban sarang

Suhu dan kelembaban sarang diukur dengan menggunakan alat Thermohygrometer. Pengambilan data suhu dan kelembaban sarang dilakukan dengan cara meletakan Thermohygrometer pada sarang Tarsius. Pengambilan data dilakukan pada pagi hari pukul 06.00-07.00 saat Tarsius belum kembali, siang hari pukul 12.0013.00 dan pada sore hari pukul 
17.00-18.00 saat Tarsius keluar mencari makanan.

2. Variabel Penunjang

$\begin{aligned} & \text { 1.Ketinggian sarang } \begin{array}{r}\text { dari } \\ \text { (mdpl). }\end{array} \\ & \text { Permukaan laut }\end{aligned}$ sengukuran ketinggian $\begin{array}{r}\text { sarang } \\ \text { (mdpl) }\end{array}$
dari permukaan laut alat
dilakukan menggunakan alan
Altimeter dengan mengambil titik
nol dari tepi pantai yang paling
dekat dengan daerah objek
penelitian.
2.Jenis vegetasi lain sekitar sarang.
Pengamatan jenis vegetasi sekitar
sarang dilakukan dengan
mengamati jenis vegetasi yang
berada disekitar sarang dengan
radius 5 m. Pengamatan ini
dibantu oleh Bpk. Yopi Mandero
suntuk menentukan nama vegetasi
tersebut.

Hasil pengamatan diolah dengan cara deskriptif yakni penguraian dan penjelasan mengenai gambarangambaran umum dari hasil pengamatan secara langsung. Untuk data mengenai suhu dan kelembaban sarang diolah dengan cara menentukan rataan dari setiap pengamatan yang dilakukan pada pagi, siang dan sore hari kemudian dianalisa secara deskriptif.

\section{HASIL DAN PEMBAHASAN}

Jenis Vegetasi

Berdasarkan hasil penelitian jenis vegetasi, ditemukan bahwa semuanya adalah pohon jenis Ficus $s p$, Penelitian Shekell, dkk. dalam Masala (1996) menyatakan bahwa Tarsius yang ada di Cagar Alam Tangkoko lebih memilih rongga pohon terutama pohon Ficus spsama halnya yang dikemukakan oleh Gursky (1988) yang menyatakan bahwa di Cagar Alam Tangkoko

umumnya pohon sarang Tarsius adalah tumbuhan Ficus caulocarpa. Jenis vegetasi yang ditemukan dalam penelitian ini adalah lima pohon Ficus spyang masih memiliki pohon induk, yaitu pohon Alstonia scholaris yang digunakan pohon Ficus spsebagai pohon induk. Sedangkan lima sarang lainnya sudah tidak memiliki pohon induk yaitu pohon yang digunakan pohon Ficus $s p$ telah mati sehingga membentuk lubang tengah pada pohon Ficus $s p$. Jenis vegetasi yang dijadikan sarang Tarsius dapat dilihat pada Tabel 1. 
Tabel 1. Jenis Vegetasi dan Lingkaran Pohon Sarang

\begin{tabular}{lll}
\hline Sarang & Jenis vegetasi yang dijadikan sarang & $\begin{array}{l}\text { Lingkaran } \\
\text { pohon }(\mathrm{m})\end{array}$ \\
\hline S1 & Ficus sp. & 5,19 \\
S2 & Alstonia scholaris dalam Ficus virens & 6,35 \\
S3 & Alstonia scholaris dalam Ficus virens & 11,38 \\
S4 & Ficus virens & 8,54 \\
S5 & Alstonia scholaris dalam Ficus benjamina & 8,75 \\
S6 & Alstonia scholaris dalam Ficus virens & 8,44 \\
S7 & Ficus sp. & 5,60 \\
S8 & Ficus virens & 9,31 \\
S9 & Alstonia scholaris dalam Ficus virens & 10 \\
S10 & Ficus sp.( pohon mati) & 8,13 \\
\hline
\end{tabular}

Keterangan : S1-S10 = Sarang 1 -Sarang10

Pada umumnya satwa primata lebih memilih vegetasi pohon sebagai tempat untuk digunakan sebagai sarang dan sebagai tempat untuk beristirahat. Seperti halnya satwa primata lainnya, Tarsius lebih banyak mendiami pohon-pohon besar yang sesuai dengan kebutuhan Tarsius. Dari hasil pengamatan ditemukan bahwa Tarsius umumnya memilih pohon Ficus sp sebagai sarang utama. Hal ini dibuktikan dari sepuluh objek yang digunakan sebagai materi penelitian adalah pohon jenis Ficus sp.

Seperti halnya yang dikemukakan oleh Wirdateti dan Hadi Dahrudin (2006) dalam penelitiannya menyatakan bahwa salah satu jenis pohon yang digunakan sebagai sarang oleh Tarsius adalah jenis Ficus sp.Tarsius diduga memilih pohon Ficus $s p$ sebagai sarang karena pohon tersebut mempunyai akar-akar pohon yang mempermudah Tarsius untuk berpegangan. Selain itu, pohon Ficus $s p$ yang terbentuk oleh akar-akar membentuk lubang-lubang kecil sehingga Tarsius dapat berteduh dari hujan maupun cahaya matahari dan menghindar dari predator.

\section{Lingkaran Pohon}

Hasil pengukuran lingkaran pohon sarang Tarsius ditemukan bahwa dari sepuluh objek pengamatan sarang Tarsius, pohon yang digunakan sebagai sarang Tarsius dengan lingkaran terkecil terdapat pada sarang pertama dengan panjang lingkaran adalah 5,19 meter dan pohon dengan lingkaran terbesar adalah pada sarang yang ketiga 11,38 meter dengan rataan lingkaran pohon adalah 8,169 m (tabel $1)$.

Pemilihan pohon sebagai
sarang Tarsius termasuk dalam kegiatan perlindungan dari gangguangangguan dari predator baik hewan pemangsa maupun manusia. Pemilihan besar lingkaran pohon diatas 5 meter oleh Tarsius untuk mendapatkan sarang yang yang sulit dijangkau oleh predator. Karena hasil pengamatan dilapangan menunjukan bahwa pohon Ficus sp yang berdiameter diatas 5 meter memiliki banyak lubang-lubang kecil yang tepat untuk dijadikan tempat tinggal untuk Tarsius.

\section{Bentuk Sarang}

Hasil penelitian bentuk sarang Tarsius ditemukan bahwa sarang 
Tarsius terbentuk dari akar-akar pohon Ficus sp yang naik ke atas dan membungkus pohon induk. akar-akar tersebut membentuk lubang-lubang kecil yang tidak dan saling sambungmenyambung antara lubang satu dengan lubang yang lain. Lubanglubang tersebut yang digunakan Tasius untuk dijadikan sarang. Dalam lubanglubang yang dibentuk oleh akar-akar pohon Ficus sp terdapat urat-urat pohon yang digunakan Tarsius untuk berpegangan. Pengamatan di lapangan juga ditemukan bahwa bentuk sarang Tarsius tidak beraturan. Lubanglubang sarang umumnya berbentuk bulat lonjong dan ada yang berbentuk persegi seperti pada gambar 1 .

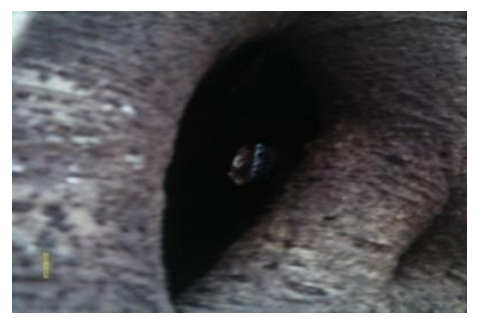

Sepuluh sampel yang dijadikan objek pengamatan lima diantaranya tidak memiliki pohon induk sehingga membentuk lubang tengah. Hasil penelitian ditemukan bahwa lubang tengah tersebut digunakan Tarsius sebagai sarang karena lubang tengah yang terbentuk memiliki jalinan akarakar yang banyak sehingga mempermudah Tarsius untuk berpegangan dan melompat dari tempat yang satu ke tempat yang lain. Pohon yang memiliki lubang tengah juga memiliki lubang-lubang kecil yang menjadi akses keluar masuk bagi Tarsius. Peranan lubang sarang bagi

Gambar 1. Bentuk Sarang Tarsius

tarsius bermanfaat, karena selain tempat untuk beristirahat dan berlindung dari cahaya matahari dan hujan juga sebagai tempat pengamatan baik dalam mencari makanan maupun untuk menghindar dari serangan predator.

Sarang Tarsius umumnya gelap dan kurang mendapatkan sinar matahari. Hal ini diperjelas oleh penelitian Mackinnon dan Mackinnon, (1980) dalam Wirdateti dan Hadi Dahrudin, (2006) yang menyatakan bahwa tempat bersarang Tarsius bercirikan relatif gelap dan terlindung dari angin, hujan dan terlindung dari pemangsa. Bentuk akar-akar yang naik

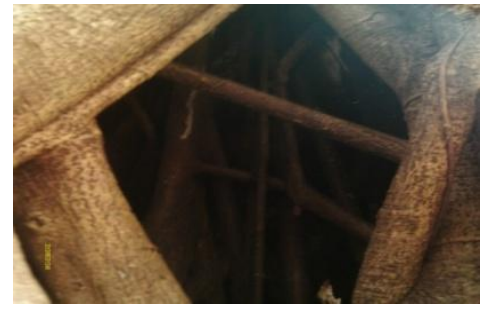

membungkus pohon induk dan lubang tengah yang terdapt pada pohon Ficus $s p$ dapat dilihat pada Gambar 2.

Tarsius tidak hanya berada dalam satu lubang sarang saja, Tarsius mengusai seluruh lubang yang ada pada pohon Ficus sp. Tarsius dapat berpindah-pindah dari lubang satu ke lubang lainnya pada pohon tersebut. Pengusaan lubang-lubang pohon menunjukan bahwa Tarsius mampu menghindari serangan-serangan predator yang dapat menyerang kapan saja. Selain itu, penguasaan ini menunjukan bahwa Tarsius memiliki wilayah sediri disetiap kelompok. 

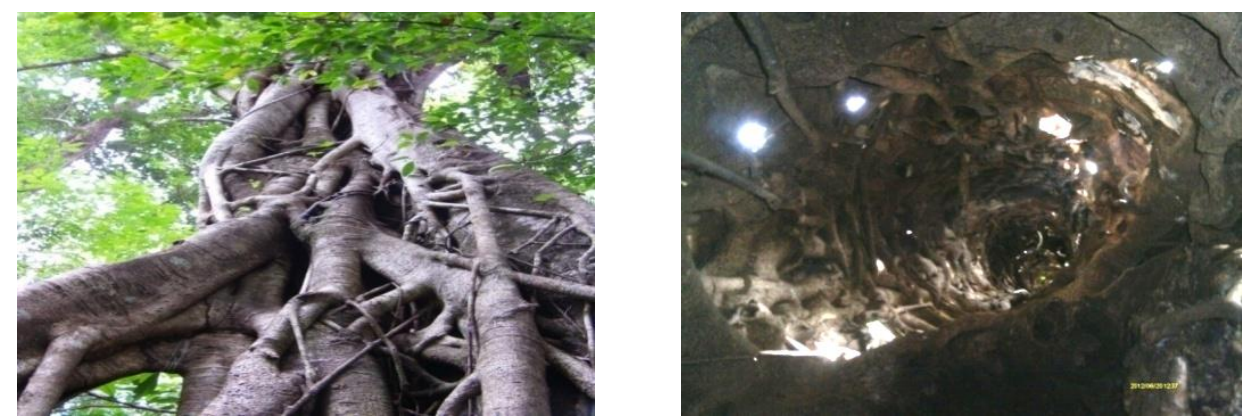

Gambar 2.Lubang-Lubang Pada Pohon dan Lubang Tengah Pada Pohon

\section{KetinggianSarang Dari Permukaan Tanah}

Tarsius merupakan satwa alboreal yang artinya hidup di pohon (Supriatna, 2000). Hasil penelitian mengenai ketinggian sarang dari permukaan tanah ditemukan bahwa Tarsius banyak mendiami sarang dengan ketinggian yang bervariasi antara $1,5 \mathrm{~m}$ sampai $13 \mathrm{~m}$. Hasil penelitian ini tidak menunjukkan perbedaan yang siknifikan dengan hasil penelitian sebelumnya oleh Widateti dan Dahrudin (2006) yang menyatakan bahwa ketinggian sarang Tarsiusdi Cagar Alam Tangkoko sekitar $3 \mathrm{~m}$ sampai $15 \mathrm{~m}$.

Tabel 2. Ketinggian Sarang Dari Permukaan Tanah.

\begin{tabular}{llc}
\hline \multirow{2}{*}{ Sarang } & Jenis vegetasi yang dijadikan sarang & $\begin{array}{c}\text { Jarak dari permukaan tanah } \\
(\mathrm{m})\end{array}$ \\
\hline S1 & Ficus sp. & 2,3 \\
S2 & Alstonia scholaris dalam Ficus virens & 8,1 \\
S3 & Alstonia scholaris dalam Ficus virens & 13 \\
S4 & Ficus virens & 9 \\
S5 & Alstonia scholaris dalam Ficus benjamina & 7,6 \\
S6 & Alstonia scholaris dalam Ficus virens & 9,2 \\
S7 & Ficus sp. & 1,5 \\
S8 & Ficus virens & 6,9 \\
S9 & Alstonia scholaris dalam Ficus virens & 11,5 \\
S10 & Ficus sp. ( pohon mati) & 7,1 \\
\hline
\end{tabular}

Keterangan : S1-S10 = Sarang1-Sarang10

\section{Suhu Dalam Sarang}

Hasil pengamatan mengenai suhu sarang Tarsius, pada pagi hari berkisar antara $20.85-21,9^{\circ} \mathrm{C}$ sedangkan pada siang hari antara $23,7-$ $24,25^{\circ} \mathrm{C}$ dan pada sore hari antara $23,85-24^{\circ} \mathrm{C}$. Hal ini menunjukkan bahwa Tarsius lebih menyukai tempat yang memiliki suhu minimum $20,85^{\circ} \mathrm{C}$ sampai suhu maksimum $24,25^{\circ} \mathrm{C}$. Dengan nilai rata-rata pada pagi hari $20,97^{\circ} \mathrm{C}$, siang hari $24,03^{\circ} \mathrm{C}$ dan pada sore hari $23,92^{\circ} \mathrm{C}$. Suhu tertinggi didapati pada siang hari karena pada waktu siang terjadi cuaca yang sangat panas yang mengakibatkan suhu menjadi sangat tinggi. Sedangkan suhu terendah didapati pada pagi hari karena pada malam hari dengan kondisi hutan yang 
sedang basah karena hujan rendah. mengakibatkan suhu menjadi sangat

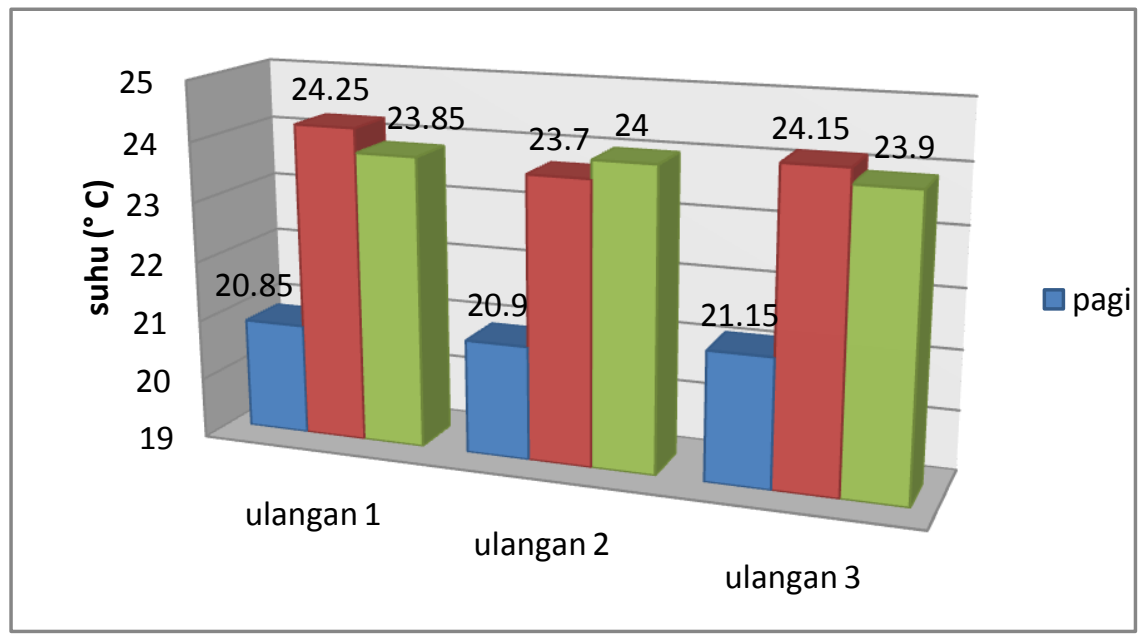

\section{Gambar 3. Suhu Dalam Sarang}

Suhu mempunyai peran penting pada setiap kehidupan satwa liar. Dimana suhu dapat mempengaruhi produktifitas satwa liar tesebut. Pada Tarsius, suhu yang tidak sesuai dapat memberikan dampak buruk bagi satwa tersebut. Seperti dalam penelitian Kiroh (2009), dalam penangkaran Tarsius diluar habitat aslinya (ex-situ), suhu dan kelembaban yang tidak sesuai dapat mengakibatkan ekor Tarsius menjadi kasar dan dapat menimbulkan lukaluka pada bagian tangan dan kaki pada Tarsius.

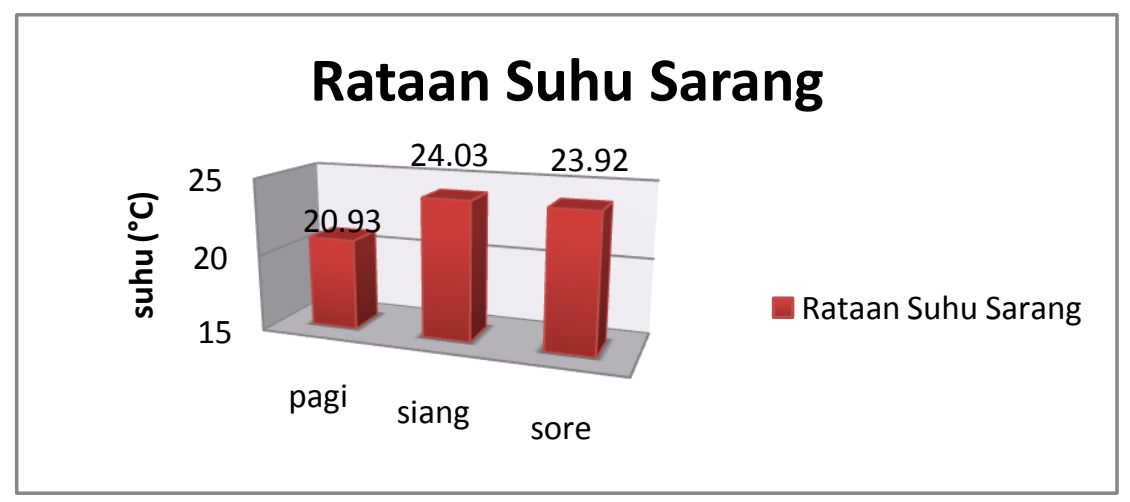

\section{Gambar 4. Rataan Suhu Sarang}

Tarsius di Cagar Alam Tangkoko kelihatannya telah terbiasa dengan kondisi seperti ini. Meskipun sering terjadi cuaca ekstrim, namun Tarsius mampu bertahan karena Tarsius berada pada habitatnya sendiri. Merker (2006)menyatakan dalam penelitiannya di Lore LinduTaman Nasional di Sulawesi, mengenai suhu bervariasi sepanjang tahun, namun suhu tertinggi rata-rata $32,9{ }^{\circ} \mathrm{C}\left(91,2^{\circ} \mathrm{F}\right)$ dan terendah dari $19,5^{\circ} \mathrm{C}\left(67,1^{\circ} \mathrm{F}\right)$. Sedangkan di utara Kalimantan di Sepilok Forest Reserve, 
ada dua musim hujan musiman (Desember-Januari dan Juli) suhu ratarata $26,7^{\circ} \mathrm{C} \quad\left(80^{\circ} \mathrm{F}\right)$ (Crompton \& Andau 1987).

\section{Kelembaban Sarang}

Sama halnya dengan suhu, kelembaban juga memiliki peranan penting dalam kehidupan satwa liar. Kelembaban dapat mempengaruhi pertumbuhuan satwa liar dimana penyesuaian kelembaban dan suhu menjadi salah satu faktor penting satwa liar dapat bertahan hidup. Hasil pengamatan kelembaban sarang Tarsius di Cagar Alam Tangkoko dengan tiga kali ulangan pada pagi, siang dan sore hari menunjukkan bahwa sarang Tarsius mempunyai kelembaban yang cukup tinggi. Data diatas menunjukkan bahwa kelembaban sarang Tarsius pada pagi hari berada pada angka kisaran antara $81,2 \%-81,6 \%$, siang $77,9 \%-78,6 \%$ dan sore hari $77,3 \%-77,5 \%$.

Tingkat kelembaban paling tinggi terdapat pada pagi hari dengan angka $81,6 \%$ dan kelembaban terendah pada sore hari dengan angka $77,37 \%$. Kelembaban paling tinggi pada pagi hari dikarenakan pada malam hari hutan menjadi lebih basah dari pada siang hari. Sedangkan tingkat kelembaban terendah pada sore hari yang dikarenakan peningkatan suhu menjadi lebih panas di waktu siang hari.

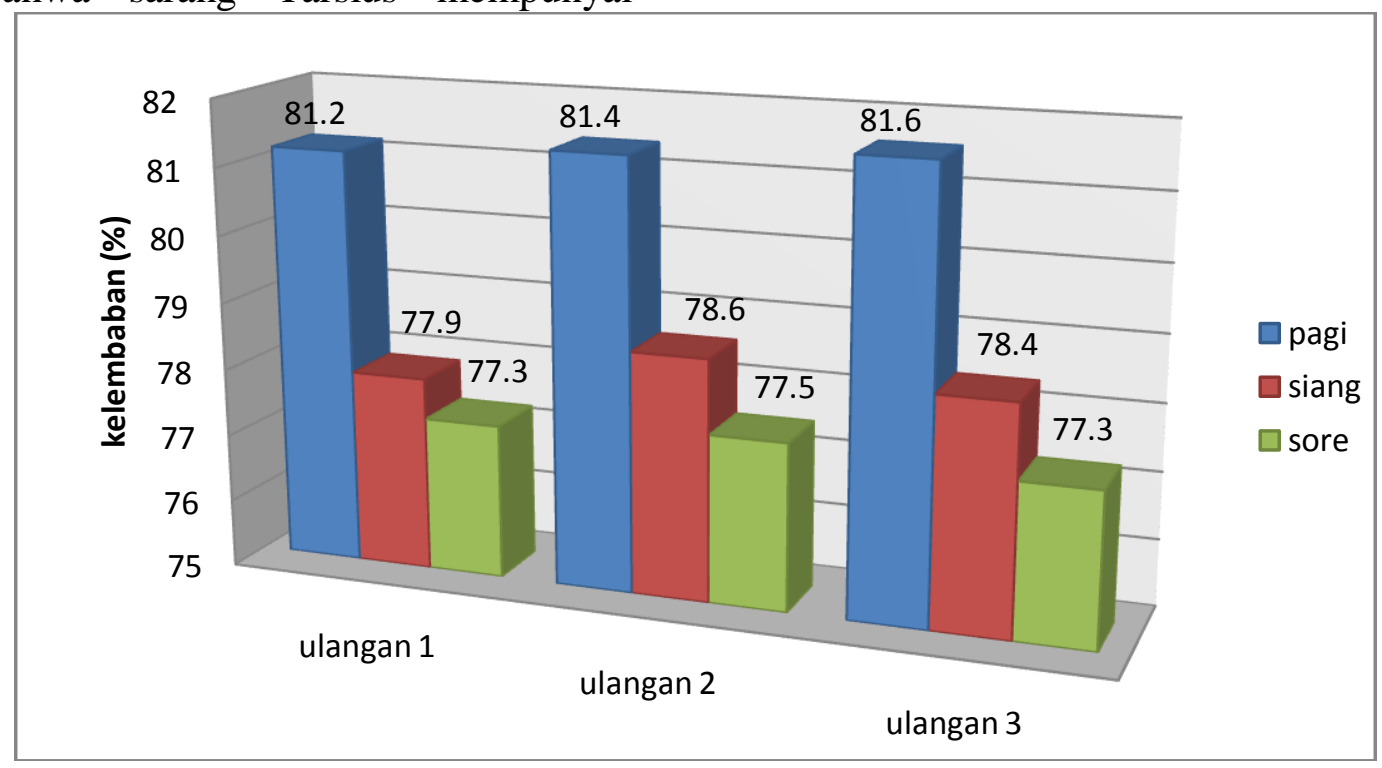

\section{Gambar 5. Kelembaban Sarang}

Tingkat kelembaban yang cukup tinggi pada sarang Tarsius menjadi salah satu penunjang pertumbuhan Tarsius. Tarsius memilih tempat yang sejuk dan agak lembab untuk dijadikan sebagai sarang. Hal tersebut diduga untuk menyesuaikan dengan karakteristik eksterior Tarsius yang memiliki bulu yang tebal. 


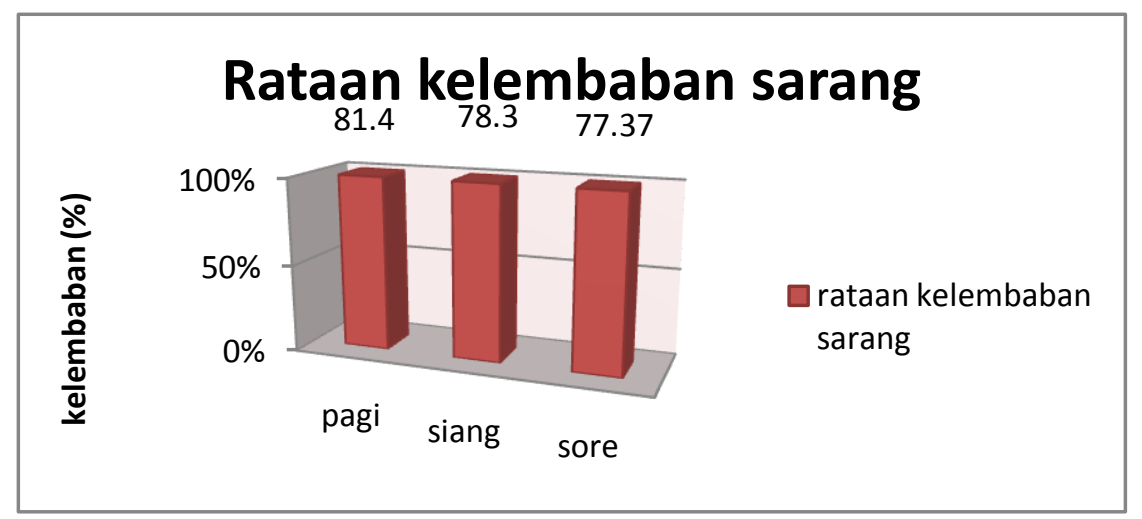

\section{Ketinggian Sarang dari Permukaan Laut (mdpl)}

Gambar 6. Rataan Kelembaban Sarang

Hasil pengukuran ketinggian sarang dari permukaan laut mengenai pohon sarang Tarsius yang digunakan sebagai objek pengamatan didapati berada pada kisaran jarak antara 25 mdpl sampai 60 mdpl. Ketinggian tersebut diukur dengan menggunakan altimeter (alat ukur ketinggian dari permukaan laut). Pohon sarang yang paling dekat dengan permukaan laut addalah sarang pertama $(25 \mathrm{mdpl})$ berada pada jalur C600 yang merupakan salah satu pohon turis atau pohon sarang yang sering dikunjungi oleh turis. Sedangkan sarang yang paling jauh dari permukaan laut adalah sarang ke tujuh sampai sarang kesepuluh yang berada pada jalur $\mathrm{K}$ 1200-1300. Rataan ketinggian sarang didapati angka rata-rata untuk ketinggian sarang Tarsius yang paling banyak dijumpai, yaitu pada ketinggian 53 mdpl.

Tabel 3. Ketinggian Sarang Dari Permukaan Laut(mdpl)

\begin{tabular}{ccc}
\hline Sarang & Lokasi $*$ & Ketinggian $(\mathrm{mdpl})$ \\
\hline S1 & C 600 & 25 \\
S2 & E1000-1100 & 50 \\
S3 & G1200 & 55 \\
S4 & G1200 & 55 \\
S5 & K1000 & 50 \\
S6 & K1100-1200 & 55 \\
S7 & K1200 & 60 \\
S8 & K1200-1300 & 60 \\
S9 & K1200-1300 & 60 \\
S10 & K1200-1300 & 60 \\
\hline
\end{tabular}

Keterangan : $*$ = kode jalur/jalan

Ketinggian sarang dari permukaan laut dapat mempengaruhi suhu dan kelembaban dari sarang Tarsius tersebut. Hal ini dikarenakan apabila sarang terlalu rendah dari permukaan laut maka akan terjadi peningkatan suhu dan kelembaban pada sarang. Suhu dataran rendah dekat pantai dapat mencapai $32^{\circ} \mathrm{C}$ dengan kelembaban dibawah $50 \%$. 
Tarsius ditemukan di hutan hujan primer dan sekunder, meskipun mereka lebih memilih hutan pertumbuhan sekunder. Hal ini mungkin karena kelimpahan yang lebih besar dari makanan di hutan pertumbuhan sekunder. Populasi Tarsius dari habitat hutan hujan dataran rendah evergreen dekat permukaan laut ke hutan hujan pegunungan rendah sampai $1500 \mathrm{~m}$. Tarsius juga telah ditemukan di hutan bakau dan hutan semak belukar (Wright, et al, 2003 dalam Shekelle dkk 2008).

\section{Jenis Vegetasi Sekitar Sarang}

Setiap pohon yang dijadikan sebagai sarang Tarsius mempunyai struktur tumbuhan disekitar yang medukung sehingga mempermudah Tarsius untuk masuk ataupun keluar kedalam sarang tersebut (Lampiran Jenis Vegetasi Lain Sekitar Sarang). Hasil pengamatan vegetasi disekitar sarang Tarsius, ditemukan sekitar 24 jenis tumbuhan yang berada di sekitar sarang Tarsius. Vegetasi sekitar sarang tersebut merupakan faktor penujang suatu pohon sehingga menjadi sarang Tarsius. Dalam penelitian Wirdateti dan Hadi Dahrudin (2006) mengutarakan bahwa terdapat 54 jenis tumbuhan dari 30 famili sebagai habitat Tarsius dan delapan diantaranya adalah sarang Tarsius yang didominasi oleh pohon Ficus $s p$. Jenis tumbuhan yang paling banyak ditremukan adalah jenis Leea indica dari famili Leeaceae dengan jumlah keseluruhan dari sepuluh sarang yang di jadikan objek pengamatan adalah44 tumbuhan. Vegetasi yang berada disekitar sarang Tarsius umumnya tumbuhan dengan diameter kecil (pancang dengan diameter 5-10 $\mathrm{cm}$ ).
Diduga tumbuhan berdiameter kecil ini lebih memungkinkan Tarsius untuk dapat berpegangan mengingat Tarsius bertubuh kecil. Seperti yang dikemukakan oleh Wirdateti dan Hadi Dahrudin (2006) bahwa hewan Tarsius bertubuh kecil dan kebiasaanya melompat menyamping vertikal diantara pohon, memungkinkan Tarsius ini untuk beradaptasi pada tumbuhan dengan diameter kecil sampai menengah dengan tajuk terbuka (tidak lebat).

\section{KESIMPULAN}

Dari hasil penelitian ini disimpulkan :

1. Tarsius yang berada di Cagar Alam Tangkoko lebih banyak mendiami pohon jenis Ficus sp untuk dijadikan sebagai sarang dengan rataan lingkaran pohon $8,169 \mathrm{~m}$ dan bentuk sarang bulat memanjang dan tidak beraturan. Jarak sarang dari permukaan tanah adalah 7,62 m.

2. Rataan suhu dan kelembaban sarang Tarsius di Cagar Alam Tangkoko adalah $22,9^{\circ} \mathrm{C}$ dan $79,02 \%$.

3. Ketinggian sarang Tarsius dari permukaan laut yang paling banyak ditemukan berada pada kisaran angka rata-rata 53 mdpl.

4. VegetasidisekitarsarangTarsiusumu mnyaadalahtumbuhanberdiameterk ecildan paling banyakadalahtumbuhanjenisLeeain dicadarifamiliLeeaceae.

\section{DAFTAR PUSTAKA}

Alikodra H.S., 1990, Pengelolaan Satwa Liar I, Departemen pendidikan dan Kebudayaan Direktorat Jendral Pendidikan Tinggi Pusat Antar Universitas 
Ilmu Hayati. Institut Pertanian Bogor

Animal diversity, 2012, Tarsius tersier (Spectral tersier).

http://animaldiversity.org. diakses pada tanggal 10 Maret 2012).

Brandon-Jones, D., Eudey, A. A., Geissmann, T., Groves, C. P., Melnick, D. J., Morales, J. C., Shekelle, M. and Stewart, C.-B. 2004. Asian primate classification. International Journal of Primatology 25(1): 97-164. Diakses dari Wikipedia.org

Gursky, S., 1997. Modeling Maternal TimeBudgeds :The Impact of Laktation and Infant Transport on The Time Budgedof The Spectral Tersier, Tarsius spectrum. Disertasi Thesis. SUNY Stony Brook.

IUCN, 2012. IUCN Red List Of Threatened Species. Diakses Pada Tanggal 20 Agustus 2012

Kiroh, H. J., 2009, Kemampuan Reproduksi Monyet Kecil (Tarsius spectrum) Yang Mengkonsumsi beberapa jenis makanan dalam Kandang Penangkaran Ex-situ. Fakultas Peternakan UNSRAT. Manado.

Masala, Y., 1996, Laporan Kegiatan Hasil Penelitian Satwa Tarsius di Sulawesi Utara, SBKSDA, Sulawesi Utara. Manado.

Manabung, A. S., 2000, Tingkah laku Grooming Monyet Hitam(Macaca nigra di Cagar Alam Tangkoko. Skripsi.
Fakultas Peternakan. UNSRAT. Manado

Niemitz, C., 1979, Outline of the Behaviour of Tarsius bancanus. Dalam : The Study of Prosimian Behaviour, Doyle, G.A. dan Martin, R.d. (Eds), Academic Press, London. h: 631

Niemitz J., 1984, The Biolofy Of Tersier, Gustav Fischer Verlag, Stuttgart.

Oscar H., 2009, Studi Beberapa Perilaku Monyet Hitam Sulawesi (Macaca nigra) Dalam Pemanfaatan Pohon Berdasarkan Strata Vegetasi Hutan Di Cagar Alam Tangkoko Sulawesi Utara, Skripsi, Fakultas Peternakan UNSRAT, Manado.

Lee, R, Jon Rilleydan L. Pesik. 2000. A Pocket Guide to TangkokoDuasudara Nature Lekson Reserve. WCS. Manado

Shekelle DKK, 2008. Primates Of The Oriental Night. LIPI Press. Jakarta

Supriatna, J., 2000, Panduan Lapangan Primata Indonesia, Yayasan Obor Indonesia. Jakarta.

Wagey D.D.J., 1997, Keadaan Habitat Monyet Hitam (macaca nigra) di Cagar Alam Tangkoko-Dua sudara, skripsi, Fakultas Peternakan UNSRAT, Manado.

Wirdatetidandahrudin H., 2006, PengamatanPakandan Habitat Tarsius spectrum (Tarsius) di KawasanCagarAlamTangkokoBatu Angus, Sulawesi Utara, JurnalBidangZoologi, PusatPenelitianBiologi, 
Jurnal Zootek (“Zootek”Journal), Vol.32 No.5 : 61-73 (Januari 2013) ISSN 0852-2626

LembagaIlmuPengetahuan

Indonesia (LIPI), Bogor 16002.

Widyastuti, 1993, Flora Fauna

MaskotNasionaldanPropinsi,

PenebarSwadaya. Jakarta

Yasuma, S dan H. S. Alikodra., 1990, Mammals of Bukit Soeharto

Protection Forest. The Tropical
Rain Forest Research Project, Samarinda, Kalimantan Timur.

Yoakum, J. and W.P. Dasmann., 1971, Habitat Manipulation Practices.

In "wildlife Management Techniques"(R.H. Giles. ed), pp:173-232. The Wildlife Society, Washington, D. 